\title{
Nomenclatural Changes in the Neotropical Eumaeini (Lepidoptera, Lycaenidae, Theclinae)
}

\author{
Robert K. Robbins ${ }^{1}$ \\ Gerardo Lamas ${ }^{2}$
}

\begin{abstract}
Nomenclatural actions are taken in the Neotropical Eumaeini in advance of publication of the Atlas of Neotropical Lepidoptera Checklist. Lectotypes are designated for eleven species group names: Lycaena astiocha Prittwitz, 1865; Thecla azia Hewitson, 1873; The la beroea Hewitson, 1868; Thecla cupa Druce, 1907; Thecla daraba Hewitson, 1867; Thecla duma Hewitson, 1878; Thecla erene $a$ Hewitson, 1867; Thecla galliena Hewitson, 1867; Thecla guacanagari Wallengren, 1860; Thecla stagira Hewitson, 1867; and Thecla thoria Hewitson, 1867. Thecla duma Hewitson, 1878 and Thecla columbinia Strand, 1916 are transferred from Eumaeini to Deudorigini (Theclinae). Lycaena vanessoides Prittwitz, 1865 is transferred from Polyommatinae to Theclinae (Eumaeini). Six type localities are changed: Colombia to Africa for Thecla columbinia Strand, 1916; Amazon to Guayaquil for Thecla daraba Hewitson, 1867; Colombia to Southeast Asia for Thecla duma Hewitson, 1878; Bolivia to Western North America for Ignata illepida K. Johnson, 1992; Argentina to the United States for Strymon nivnix K. Johnson, Eisele \& MacPherson, 1990; and Dominican Republic to mainland Central and South America for Tmolus victoria $\mathrm{K}$. Johnson \& Matusik, 1989. Seven new synonyms are: Lycaena vanessoides Prittwitz, $1865=$ Thecla hygela Hewitson, 1868 syn. nov.; Thecla saepium Boisduval, $1852=$ Ignata illepida K. Johnson, 1992 syn. nov.; Thecla tyriam H.H. Druce, 1907 =Zigirina minutia K. Johnson \& Adams, 1997 syn. nov.; Thecla halciones Butler \& H. Druce, 1872 = Decussata colombiana K. Johnson, Austin, Le Crom \& Salazar, 1997 syn. nov.; Papilio celmus Cramer, 1775 = Tmolus victoria K. Johnson \& Matusik, 1989 syn. nov.; Thecla daraba Hewitson, 1867 = Thecla tyleri Dyar, 1913 syn. nov.; and Thecla galliena Hewitson, 1877 = Thecla iopas Godman \& Salvin, 1887 syn. nov. The generic name Decussata K. Johnson, Austin, Le Crom \& Salazar, 1997 is a new junior synonym of Ostrinotes K. Johnson, Austin, Le Crom \& Salazar, 1997. The unavailable infra-subspecific name Thecla orobiana forma + cosmophila Tessmann, 1928 is available as Thecla cosmophila Bridges, 1988. Seven new combinations are: Hypokopelates columbinia (Strand, 1916) comb. nov.; Mithras cosmophila Bridges, 1988 comb. nov.; Nicolaea cupa (Druce, 1907) comb. nov.; Salazaria elizabetha (Salazar, Vélez \& K. Johnson, 1997) comb. nov.; Ostrinotes halciones (Butler \& H. Druce, 1872) comb. nov.; Strephonota tyriam (H.H. Druce, 1907) comb. nov.; and Aubergina vanessoides (Prittwitz, 1865) comb. nov. The holotypes of seven eumaeines are composed of parts belonging to different species: Strymon andrewi K. Johnson \& Matusik, 1988; Decussata colombiana K. Johnson, Austin, Le Crom \& Salazar, 1997; Trochusinus elizabetha Salazar, Vélez \& K. Johnson, 1997; Ignata illepida K. Johnson, 1992; Zigirina minutia K. Johnson \& Adams, 1997; Strymon nivnix K. Johnson, Eisele \& MacPherson, 1990; and Tmolus victoria K. Johnson \& Matusik, 1989. Some parts of these holotypes are excluded to clarify the identity of these names. Three chronic
\end{abstract}

1) Department of Entomology, National Museum of Natural History, Smithsonian Institution. Washington, DC 20560-0127, USA. E-mail: robbins.robert@nmnh.si.edu

2) Museo de Historia Natural, Universidad Nacional Mayor de San Marcos. Apartado 14-0434, Lima-14, Peru. E-mail: d190090@unmsm.edu.pe.so 
misspellings are corrected: Papilio ganimedes Cramer, 1775, for Papilio ganymedes [sic] Fabricius, 1776; Thecla atnius Herrich-Schäffer, [1853], for Thecla atrius [sic] Herrich-Schäffer, [1858]; and Rusticus minyas Hübner, [1809], for Rusticus minijas [sic] Poey, 1832. The name Electrostrymon minikyanos K. Johnson \& Matusik, 1988, is treated as a nomen dubium. The subjective synonymy of Thecla guacanagari Wallengren, 1860, and Thecla azia Hewitson, 1873, is referred to the International Commission on Zoological Nomenclature for conditional suppression of the first name. Precedence for the names Papilio dion Schaller, 1788, and Hesperia columella Fabricius, 1793, is reversed under Article 23.9.1 of the International Code of Zoological Nomenclature.

KEY WORDS. Theclinae, Eumaeini, Nomenclature, Holotype Exclusions

A number of nomenclatural problems were uncovered in preparing the Eumaeini (Lepidoptera, Lycaenidae, Theclinae) for the Atlas of Neotropical Lepidoptera Checklist (hereafter "Atlas Checklist”, RoBBINS 2002b). The purpose of this note is to correct these problems in advance of the Atlas Checklist. Some specific names are transferred either to or from the Neotropical Eumaeini, lectotypes are designated where this action will stabilize the identity of names, specific and generic names are synonymized, type localities are changed, new combinations are proposed, chronic misspellings of specific names are corrected, one name is made a nomen dubium, holotypes whose parts belong to more than one species have some parts excluded, the authorship of Thecla cosmophila Tessmann is discussed, the identity of Thecla daraba Hewitson is resolved, Thecla guacanagari Wallengren is referred to the International Commission on Zoological Nomenclature for conditional suppression, and priority for a well-known specific name is reversed. Citations to original descriptions are listed in LAMAS et al. (1995). Some newly discovered homonyms have been replaced elsewhere (ROBBINS 2002a).

\section{Names transferred from the Eumaeini to Deudorigini}

\section{Hypokopelates columbinia (Strand, 1916), comb. nov.}

Thecla columbinia Strand, 1916: 17.

Type locality: Colombia (?), probably Africa.

Thecla columbinia Strand, 1916, was described from a male labeled Colombia. It does not seem to have been noted that the illustrated holotype (Figs 1-2) belongs to the tribe Deudorigini (Theclinae), probably the African genus Hypokopelates Druce, to which it is transferred, new combination. It has hindwing tails at veins $2 \mathrm{~A}$ and $\mathrm{Cu} 2$, androconia on the dorsal surface of the hindwing costa, and appears to have a "brush" of scales on the ventral surface of the hindwing costa. These traits occur in many, if not most, members of the Deudorigini (ELIOT 1973). The wing pattern of Thecla columbinia is similar to that of $H$. ultramarina Stempffer, 1964, but the authors do not know enough about Hypokopelates to determine whether the holotype illustration is sufficient to place this name with certainty. ACKERY et al. (1995) did not mention the name, so it is suspected that this is the first time that this name has been applied to the African fauna. Unfortunately, the holotype has not been located. 

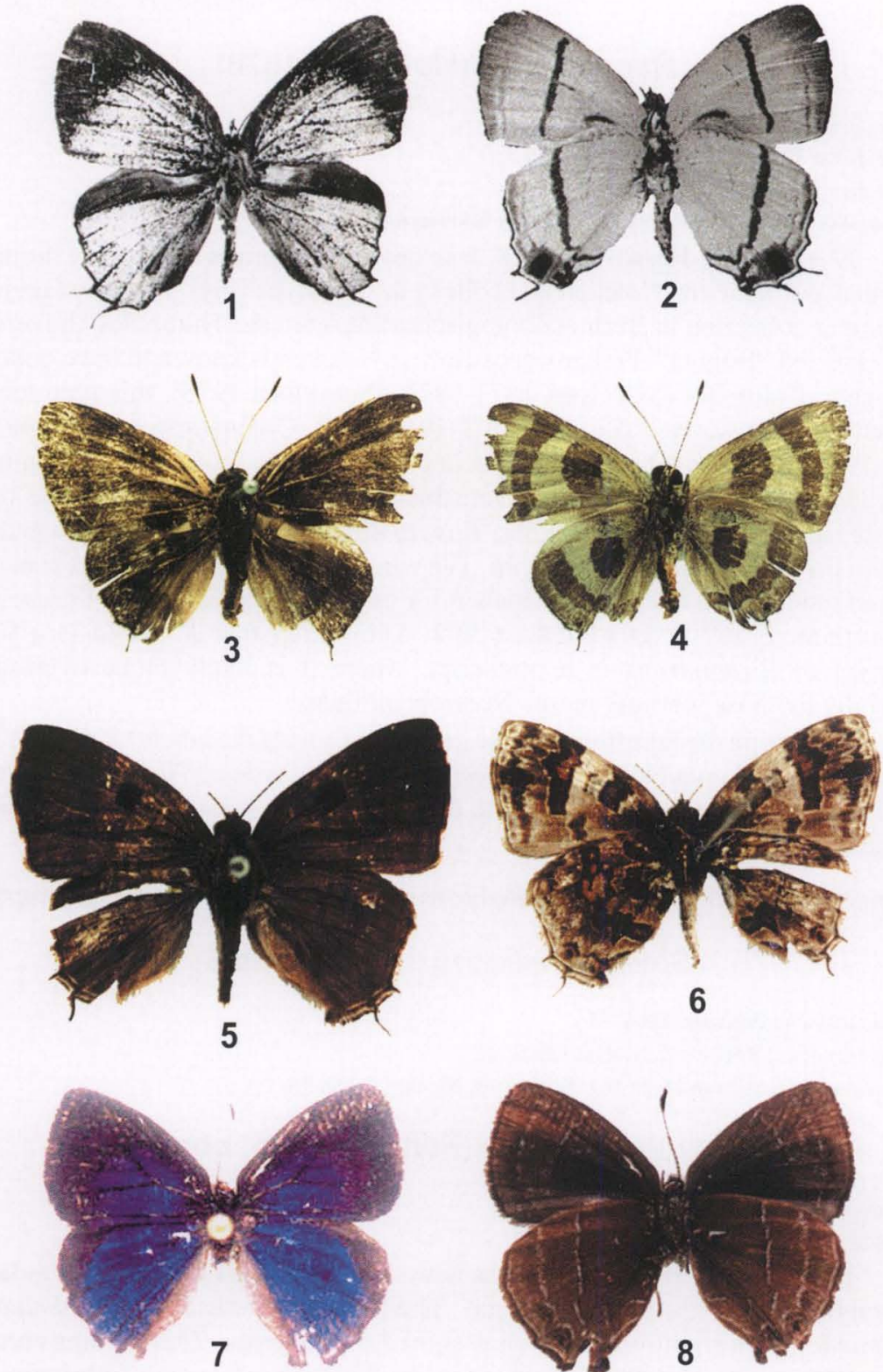

Figs 1-8. Reproduction of original illustration of the dorsal and ventral wing surfaces of Thecla columbinia Strand (1-2), which was described from Colombia, but is probably African; dorsal and ventral wing surfaces of the lectotype of Thecla duma Hewitson (3-4), which was described from Colombia, but is probably from Southeast Asia; dorsal and ventral wing surfaces of the holotype of Lycaena vanessoides Prittwitz (5-6), which was mistakenly described in Polyommatinae; dorsal and ventral wing surfaces of the male holotype of Salazaria elizabetha (Salazar, Vélez \& K. Johnson) (7-8). 


\section{Rapala duma (Hewitson, 1878)}

Thecla duma Hewitson, 1878: 211.

Rapala duma; Eliot \& D'Abrera, 1992: 511.

Rapala abnormis Elwes, [1893]: 642.

Type locality: Colombia, Bogotá (?), probably Southeast Asia.

Thecla duma Hewitson, 1878, was described from at least one Colombian male that Wilhelm von Nolcken had collected. A syntype (Figs 3-4) is extant in the Staudinger collection in Berlin (Zoologisches Museum der Humboldt Universität) and is labeled "Bogota." Perhaps because von Nolcken is known to have collected in Bogotá, Colombia (NOLCKEN 1871-1872, PAPAVERO 1973), this type locality has not been questioned (i.e., DRAUDT 1919-1920, COMSTOCK \& HUNTINGTON 1959-1964) even though no other specimens have been found in that country or elsewhere in the Neotropics. However, this syntype of $T$. duma is a male of the widespread Southeast Asian species, Rapala abnormis Elwes, [1893], which belongs to the thecline tribe Deudorigini. The wing pattern of this species is conspicuous and unique, and cannot be mistaken for any other species in the Eumaeini or Deudorigini. ELIOT \& D'ABRERA (1992: 511) noted that $R$. duma is a senior synonym of $R$. abnormis in a postscript, where it is likely to be overlooked, especially by those working on the Neotropical fauna.

Lectotype designation. A male in Berlin, bearing the labels "SYN-/TYPE"; "Duma", and "Bogota/Nolcken.", is designated a lectotype of Thecla duma Hewitson, 1878, with the taxonomic purpose of providing the name Thecla duma with a unique name-bearing type.

\section{Names transferred from the Polyommatinae to Theclinae (Eumaeini)}

\section{Strymon astiocha (Prittwitz, 1865)}

Lycaena astiocha Prittwitz, 1865: 324.

Strymon astiocha; Robbins \& Nicolay, 2002: 98.

Thecla faunalia Hewitson 1868: 161; Robbins \& Nicolay, 2002: 98.

\section{Aubergina vanessoides (Prittwitz, 1865) comb. nov.}

Lycaena vanessoides Prittwitz, 1865: 323.

Thecla hygela Hewitson, 1868: 30 syn. nov.

PRITTWITZ (1865) described as new six Neotropical Lycaenidae under the general heading "Thecla und Lycaena". The first four (acaste, hirsuta, imma and megamede) have traditionally been assigned to the genus Thecla Fabricius and the last two (astiocha and vanessoides) to the genus Lycaena Fabricius (i.e., KiRBY 1871, DRAudT 1919-1920, COMSTOCK \& HunTINGTON 1959-1964, LAMAS et al. 1995) although PRITTWITZ himself did not unequivocally assign any of those six specific names to either generic name. It can be assumed from PRITTWITZ's introduction and subsequent text that he was following the arrangement proposed in DOUBLEDAY's Genera of diurnal Lepidoptera (WESTWOOD 1850-1852), at that time widely regarded as the most authoritative text on 
butterflies of the world. In the Genera text for the Lycaenidae (pp. 468-504), Thecla (including 144 species) immediately precedes Lycaena (with 199 species), these genera being roughly equivalent to modern-day Eumaeini and Polyommatinae. PRITTWITZ's entries of known species under "Thecla und Lycaena" follow the arrangement in WESTWOOD (e.g., PRITTWITZ's sequential citation of Eumaeini marsyas (Linnaeus, 1758), meton (Cramer, 1779), phaleros (Linnaeus, 1767), polybe (Linnaeus, 1763), eurisides (Hübner, 1823), simaethis (Drury, 1773), ... etc., correspond to species numbers $1,14,15,16,20,32, \ldots$ etc. in WESTWOOD's Thecla and his sequential citation of Polyommatinae cassius (Cramer, 1775) and hanno (Stoll, 1790) correspond to species 53 and 186 of Lycaena). Careful examination of PRITTWITZ's text reveals that he compared acaste, hirsuta, imma and megamede to species listed by WESTWOOD under Thecla and compared astiocha and vanessoides to species included by WESTWOOD in Lycaena. Thus, it appears safe to follow previous authors in assuming that these two last species were regarded by PRITTWITZ as belonging in Lycaena.

Two male syntypes of Lycaena astiocha and the male holotype of Lycaena vanessoides (Figs 5-6), which are in Berlin (Zoologisches Museum der Humboldt Universität), are Eumaeini. Lycaena astiocha was previously transferred to Strymon Hübner and treated (as having been originally described in Thecla) as a senior synonym of Thecla faunalia Hewitson, 1868 (ROBBINS \& NICOLAY 2002). Lycaena vanessoides is transferred to Aubergina Johnson, comb. nov., and is treated as a senior synonym of Thecla hygela Hewitson, 1868, syn. nov.

Lectotype designation. A male in Berlin, bearing the labels "SYN-/TYPE"; "Origin."; "Coll. Prittwitz/Rio"; and "Astiocha/Prittw.", is designated a lectotype of Lycaena astiocha Prittwitz, 1865, with the taxonomic purpose of providing the name Lycaena astiocha with a unique name-bearing type.

\section{Chronically misspelled specific names}

Papilio ganimedes Cramer, 1775 (correct original spelling), has often been spelled as $P$. ganymedes [sic] (e.g., KIRBY 1871, DRAUDT 1919-1920, COMSTOCK \& HUNTINGTON 1959-1964) since FABRICIUS (1776) introduced this error. Similarly, Thecla atnius Herrich-Schäffer, [1853] 1775 (correct original spelling), has been widely known as $T$. atrius [sic], a name that was mistakenly introduced by HERRICH-SCHÄFFER ([1858]). KIRBY (1871) and HEWITSON (1877) used the original spelling, but later authors (e.g., DRAUDT 1919-1920, COMSTOCK \& HUNTINGTON 1959-1964) incorrectly listed it as T. atrius [sic].

There has been considerable controversy about the original spelling of the specific name Eumaeus minyas (Hübner, [1809]). The name appeared for the first time in the legend for figures 1-4 of plate [97] in the first volume of HÜBNER's Sammlung..., and some (e.g., HEMMING 1967, COWAN 1970) have read it as minijas, while others (e.g., W.D. Field unpubl. data) believe it was written as minÿas, with a diaeresis over the "y". The first subsequent use of the specific epithet was by HÜBNER himself ([1819]), on page 67 of his Verzeichniss..., where he cites it twice as minyas (no diaeresis over the " $y$ "), and again as minyas on page 17 of the index ("Anzeiger") to that work, published in 1827. The first use of the spelling minijas was by POEY (1832).

Revta bras. Zool. 19 (Supl. 1): 197 - 214, 2002 
Contrary to the views of HEMMING (1967) and Cowan (1970), it is concluded that the name was originally spelled as minyas, being later emended by HÜBNER ([1819]) to minyas by deletion of the diaeresis over the " $y$ ". This conclusion is based on the following evidence: 1) To see how a letter " $\mathrm{j}$ " was calligraphed in HÜBNER's Sammlung, the specific name pompejus on plate [124] in volume 1 was examined; here the letter " $\mathrm{j}$ " is shown as having a short element at the top projecting to the left, and this projection is not present on the letter in question on HÜBNER's plate [97]. 2) In at least one other instance, on plate [97] of vol. 2 of the Sammlung, the letter " $y$ " has a diaeresis, in the name Laertias cÿrus; it seems illogical to assume this name was spelled "cijrus". 3) Clearly, minyas was the spelling used subsequently and exclusively by Hübner. 4) The word "minijas" does not appear to mean anything in classical Greek or Latin while Minyas was the Greek king of Orchomenus and mythical ancestral hero of the race of the Minyae (SEYFFERT 1995). Accordingly, minyas is regarded as the correct original spelling of the name, with the correction mandated by Article 32.5.2.1 of the Code.

\section{Exclusion of parts of chimeric holotypes}

Seven Neotropical Eumaeini holotypes are composed of parts belonging to more than one species. Under Article 73.1.5 of the International Code of Zoological Nomenclature (ICZN 1999), some parts of these holotypes are excluded from the holotype with the taxonomic purpose of best clarifying identification of the name.

\section{Strymon toussainti (Comstock \& Huntington, 1943)}

Strymon toussainti Comstock \& Huntington, 1943: 84.

Strymon andrewi K. Johnson \& Matusik, 1988: 228 Robbins \& Nicolay, 1999: 334.

The holotype of Strymon andrewi K. Johnson \& Matusik, 1988 (stated to be male in the original description), consists of a female of $S$. toussainti (Comstock \& Huntington, 1943) and male genitalia of a different species, probably S. eurytulus (Hübner, [1819]) (RoBBINS \& NiCOLAY 1999). The sex of the adult was determined by its foreleg, which possesses a pretarsus and five-segmented tarsus. Strymon andrew $i$ was treated as a junior synonym of $S$. toussainti (ROBBINS \& NICOLAY 1999). To sustain this synonymy, the male genitalia are excluded from the holotype.

\section{Calycopis cecrops (Fabricius, 1793)}

Hesperia cecrops Fabricius, 1793: 270.

Calycopis cecrops; Scudder 1887: 108.

Strymon nivnix K. Johnson, Eisele \& MacPherson, 1990: 28; Robbins \& Nicolay 2002: 95.

Type locality of S. nivnix: Argentina (?), probably United States.

The hindwings and forewings of the holotype of Strymon nivnix K. Johnson, Eisele \& MacPherson, 1990, belong to different species (ROBBINS \& NICOLAY 2002). The hindwings appear to be Calycopis cecrops (Fabricius, 1793) while the forewings cannot be identified with certainty, and the illustrated genitalia are not identifiable. This name was treated as a synonym of Calycopis cecrops, and the hindwings were incorrectly designated a lectotype (ROBBINS \& NICOLAY 2002). To 
sustain this synonymy, the genitalia and forewings are excluded from the holotype. Although this species was described from Argentina, it does not occur in the Neotropics.

\section{Salazaria elizabetha (Salazar, Vélez \& K. Johnson, 1997), comb. nov.}

Trochusinus elizabetha Salazar, Vélez \& K. Johnson, 1997: 10.

The illustrated holotype of Trochusinus elizabetha Salazar, Vélez \& K. Johnson, 1997, (Figs 7-8) is a composite of partial female genitalia lacking identifiable traits and of an adult male that belongs Salazaria D'Abrera \& Bálint. The original description text states that the holotype is a female, but the original description figure legend refers to the holotype as a male. The androconia and pattern on the ventral surface of the wings in the holotype illustration (Fig. 8) identifies it as a male of a previously undescribed species of Salazaria. The female genitalia are excluded from the holotype so that this name becomes Salazaria elizabetha comb. nov.

\section{Strephonota tyriam (H.H. Druce, 1907) comb. nov.}

Thecla tyriam H.H. Druce, 1907: 595.

Zigirina minutia K. Johnson \& Adams, 1997: 38, syn. nov.

The illustrated male holotype of Zigirina minutia K. Johnson \& Adams, 1997, and the illustrated genitalia belong to different genera. JOHNSON et al. (1997: 38) remarked that the male genitalia of this species "suggest extremes in the genitalic configuration due perhaps to allometry in this smaller species." However, allometry is an unlikely explanation because the forewing length of the holotype is $16.5 \mathrm{~mm}$, not the $13.5 \mathrm{~mm}$ stated in the original description. It appears to us that the adult holotype is indistinguishable from male Thecla tyriam H.H. Druce, 1907, and that the genitalia belong to the unrelated Thecla latagus Godman \& Salvin, 1887 (a relationship suggested in the original description) or one of its close relatives. To complicate matters, the illustrated male holotype of $Z$. minutia, which was supposed to be deposited in the Natural History Museum (BMNH), London, is in the American Museum of Natural History, where it has the labels that were supposed to be on the holotype of Robustina prima Johnson, Austin, Le Crom \& Salazar, 1997. The genitalia are excluded from the holotype of Z. minutia. Zigirina minutia is a new synonym of Strephonota tyriam, new combination.

\section{Ostrinotes halciones (Butler \& H. Druce, 1872) comb. nov.}

Thecla halciones Butler \& H. Druce, 1872: 108.

Decussata colombiana K. Johnson, Austin, Le Crom \& Salazar, 1997: 51, syn. nov.

Decussata colombiana K. Johnson, Austin, Le Crom \& Salazar, 1997, is the type species of Decussata K. Johnson, Austin, Le Crom \& Salazar, 1997. Its illustrated holotype adult is a female of Ostrinotes K. Johnson, Austin, Le Crom \& Salazar, 1997, probably $O$. halciones (Butler \& H. Druce, 1872), but its illustrated genitalia are male, probably belonging to Theclopsis Godman \& Salvin, 1887, or Siderus Kaye, 1904. The rounded forewings of the illustrated adult holotype indicate 
that it is a female, and its ventral wing pattern matches that of $O$. halciones. The original description does not indicate the sex of the holotype or its type locality (the text is truncated on the bottom of page 51), but it refers to a figure of male genitalia with a long thin saccus and long thin valvae, structures that are typical of Theclopsis and some Siderus, not Ostrinotes. The male genitalia are excluded from the holotype, so that $D$. colombiana becomes a new synonym of $O$. halciones, and Decussata K. Johnson, Austin, Le Crom \& Salazar, 1997, becomes a new junior synonym of Ostrinotes K. Johnson, Austin, Le Crom \& Salazar, 1997.

\section{Celmia celmus (Cramer, 1775)}

Papilio celmus Cramer, 1775: 87.

Tmolus victoria K. Johnson \& Matusik, 1989: 525, syn. nov.

Type locality of $T$. victoria: Dominican Republic (?), probably mainland Central or South America.

The holotype (Figs 9-10) and allotype (Figs 11-12) of Tmolus victoria K. Johnson \& Matusik, 1989, are glued composite specimens with hindwings belonging to males of Celmia celmus (Cramer, 1775) (Figs 13-14) and forewings belonging to Ministrymon Clench, possibly M. albimimicus (K. Johnson, 1986) (Figs 15-16). Identification of the hindwings is based on wing pattern (Figs 13-14). Males of $C$. celmus vary in color on the dorsal surface of the hindwings from brown to blue, but females always lack the blue scales that are present in both types of $T$. victoria (Figs 9,11). Identification of the forewings is based upon wing pattern (Figs 15-16), which is the same as those of the types (Figs. 9-12). The holotype genitalia are male and belong to Ministrymon (JOHNSON \& MILLER 1991), but the definitive distinguishing characters for this genus were not illustrated or mentioned in the original description of $T$. victoria. The forewings and genitalia are excluded from the holotype, so $T$. victoria becomes a synonym of $C$. celmus syn. nov. Although T. victoria was described from the Dominican Republic, neither C. celmus nor $M$. albimimicus occurs in the Antilles.

It is rather remarkable, and truly troubling, that both the holotype of $T$. victoria, which was collected by MATUSIK, and the allotype, which was from the BMNH collection (JOHNSON \& MATUSIK 1989), are both glued composites of the same two species belonging to different genera.

\section{Satyrium saepium (Boisduval, 1852)}

Thecla saepium Boisduval, 1952: 288. '

Satyrium saepium; Ziegler 1960: 20.

Ignata illepida K. Johnson, 1992: 195 syn. nov.

Type locality of I. illepida: Bolivia (?), probably western North America.

The illustrated holotype of Ignata illepida K. Johnson, 1992 (stated to be female), is composed of a male of Satyrium saepium (Boisduval, 1852) and an unrecognizable partial female genitalia. Identification of the adult male is based upon its scent pad on the dorsal forewings and its underside wing pattern (Figs 17-18). The female genitalia are excluded from the holotype so that this name becomes Satyrium saepium, new synonym. The type locality of I. illepida was given as Bolivia, but $S$. saepium is not recorded south of Mexico. 

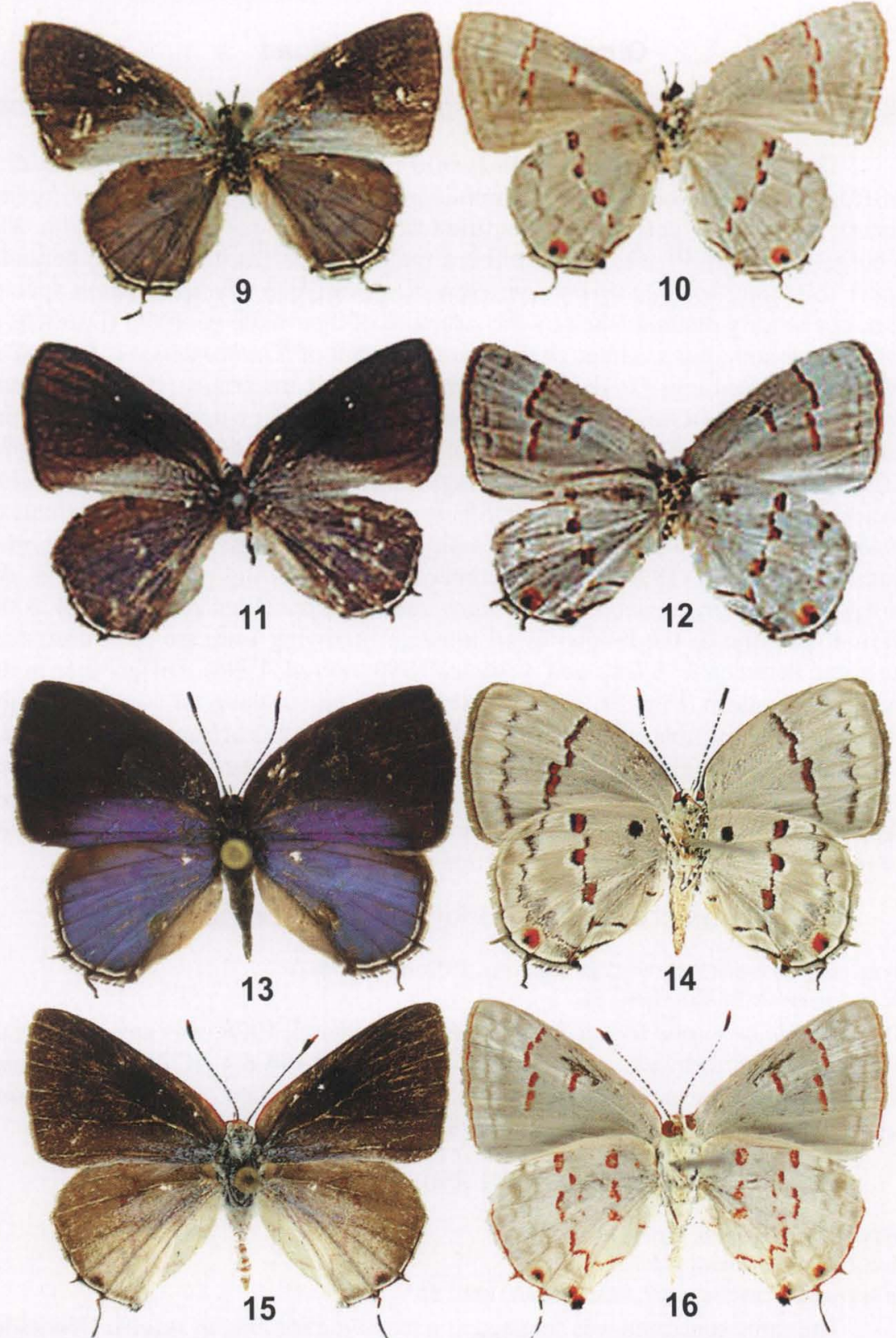

Figs 9-16. Dorsal and ventral wing surfaces of the adult holotype of Tmolus victoria K. Johnson \& Matusik (9-10), in which the forewings belong to Ministrymon Clench and the hindwings to Celmia K. Johnson; dorsal and ventral wing surfaces of the allotype of Tmolus victoria $\mathrm{K}$. Johnson \& Matusik (11-12), in which the forewings belong to Ministrymon and the hindwings to Celmia; dorsal and ventral wing surfaces of a male of Celmia celmus Cramer (13-14); dorsal and ventral wing surfaces of a male of Ministrymon albimimicus K. Johnson (15-16). 


\section{Other nomenclatural actions}

\section{Electrostrymon minikyanos K. Johnson \& Matusik, 1988: 223, nom. dub.}

The name Electrostrymon minikyanos K. Johnson \& Matusik, 1988, described from one specimen from the Dominican Republic, is made a nomen dubium because it cannot be definitively identified from its wing pattern or genitalia. The holotype (Figs 19-20) was stated to be a male, and its illustrated male genitalia appear to belong to Electrostrymon. However, Antillean Electrostrymon species cannot be readily distinguished by the structure of their male genitalia (DUARTE \& RoBBINS unpubl. data). Although the holotype adult of $E$. minikyanos is very worn and lacks its front legs (so determination of its sex is uncertain), its wing pattern appears to be that of a small female of Allosmaitia fidena (Hewitson, 1867), a species that also occurs in the Dominican Republic. The pattern and hue of the blue color on the dorsal surface of the holotype's wings is the same as all females of Allosmaitia species and is different from all male Electrostrymon species. Small individuals of Allosmaitia are known, such as the male illustrated (Figs 21-22) of A. piplea (Godman \& Salvin, 1896). The differences in ventral wing pattern between the holotype of "Electrostrymon" minikyanos and A. piplea (Figs 20,22), such as the different position of the hindwing postmedian hindwing line, are the differences illustrated between A. fidena and A. piplea (SMITH et al. 1996). Differences in the dorsal wing pattern (Figs 19,21), other than those due to the poor condition of the holotype, are those that differentiate males and females in Allosmaitia, such as a darker blue hue in males that is slightly more expansive on the forewing. Given that K. JOHNSON and associates have described seven species from holotypes composed of more than one species (previous section), Electrostrymon minikyanos is treated as a nomen dubium until further collections can clarify its identity.

\section{Mithras cosmophila (Bridges, 1988) comb. nov.}

Thecla orobiana forma + cosmophila Tessmann, 1928, nom. nud.

Thecla cosmophila Bridges, 1988: 91.

Thecla orobiana forma + cosmophila Tessmann, 1928, was described as an infra-subspecific form and is unavailable under Article 45.6.4 (ICZN 1999). However, it was used as an available specific name by BRIDGES (1988), so the name becomes Thecla cosmophila Bridges, 1988 under Article 45.5.1 (ICZN 1999).

\section{Rekoa stagira (Hewitson, 1867)}

Thecla stagira Hewitson, 1867: 113.

Rekoa stagira; Robbins, 1991: 52.

Thecla erenea Hewitson, 1867: 113; Robbins, 1991: 52

The same specimen was selected as a lectotype for Thecla stagira Hewitson, 1867, and T. erenea Hewitson, 1867, (ROBBINS 1991), but this action was incorrect because both names were clearly based on at least two separate male specimens, said to differ in the width of the brown color "...on the outer margin of the anterior wing [above]..." and the curvature of "... the band on the underside of the posterior wing..." (HEWITSON 1867). 

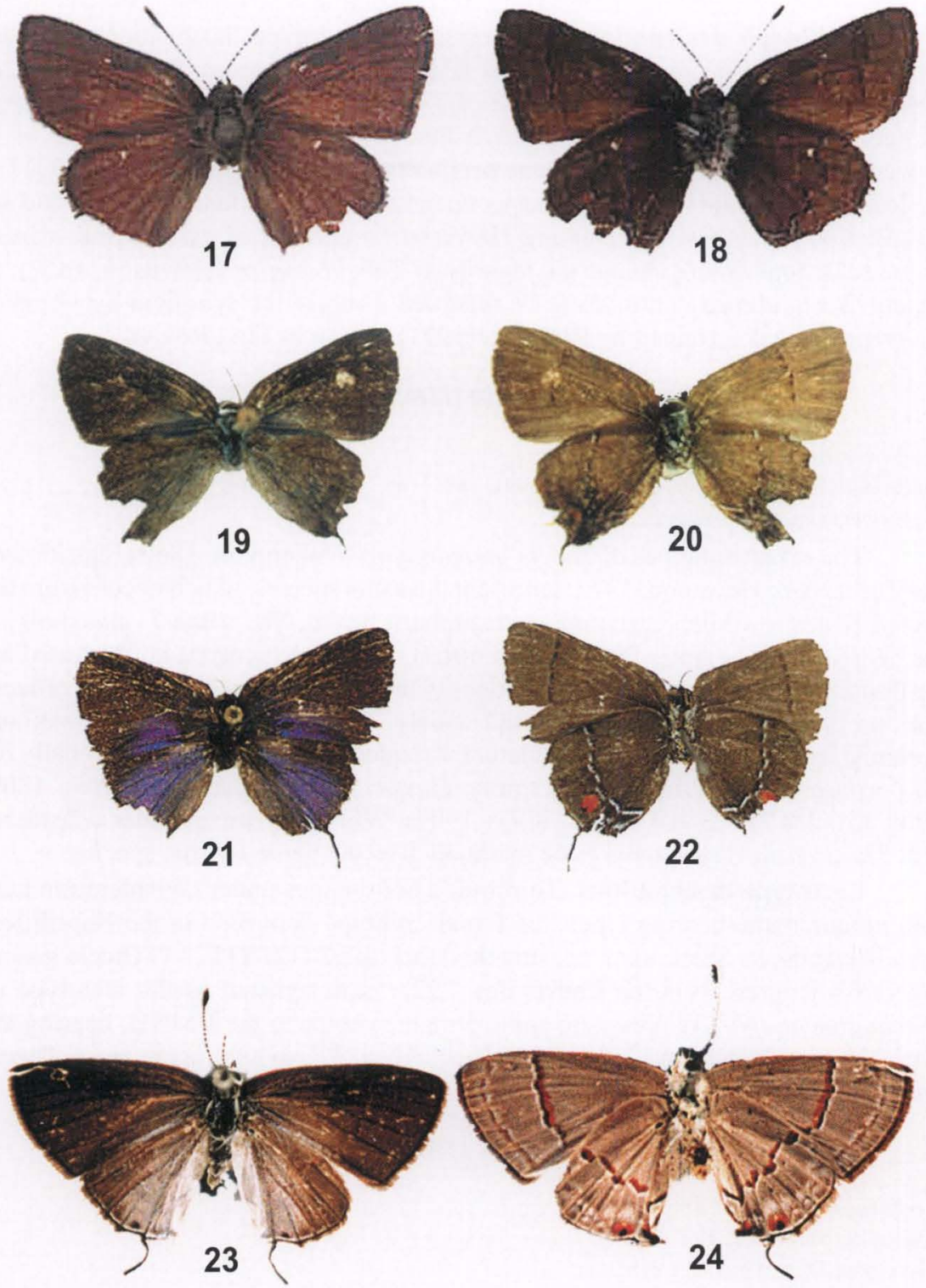

Figs 17-24. Dorsal and ventral wing surfaces of the adult holotype of Ignata illepida K. Johnson (17-18), which is a synonym of the North American Satyrium saepium Boisduval; dorsal and ventral wing surfaces of the adult holotype of Electrostrymon minikyanos $\mathrm{K}$. Johnson \& Matusik (19-20); dorsal and ventral wing surfaces of a small individual of Allosmaitia piplea (Godman \& Salvin) (21-22); dorsal and ventral wing surfaces of the lectotype of Thecla guacanagari Wallengren (23-24). 
Lectotype designations. To correct the lectotype designations of these species, the male specimen with number BMNH\# 266909, from [Brazil, Pará, Rio] Tapajós, is designated as the lectotype of $T$. stagira, and the male specimen with number BMNH\# 266908, from [Brazil, Pará], Santarém, as the lectotype of $T$. erenea (this latter specimen is the one originally designated by ROBBINS [1991] as the lectotype for both names). Both specimens are deposited in the BMNH, and are regarded by us as best representing HEwITSON's concept of stagira and erenea. These selections do not change the identity of Thecla stagira (Hewitson, 1867), of which Thecla erenea continues to be regarded a subjective synonym by virtue of the precedence determined by RoBBins (1991), acting as First Reviser.

\section{Ministrymon azia (Hewitson, 1873)}

Thecla azia Hewitson, 1873: 144.

Ministrymon azia; K. Johnson \& L. Miller, 1991: 185.

Thecla guacanagari Wallengren, 1860: 37.

The extant syntypes of Thecla guacanagari Wallengren, 1860 (Figs 23-24), and Thecla azia Hewitson, 1873, represent the same species, which occurs from the United States to Chile, Argentina, and southern Brazil. The name T. guacanagari has been used once since 1899 (EBERT 1969). Its female syntype is illustrated for the first time here (Figs 23-24), as its identity has otherwise been unknown. Thecla azia, on the other hand, has been used widely. For this reason, the International Commission on Zoological Nomenclature is requested to suppress conditionally for the purposes of the Principle of Priority Thecla guacanagari Wallengren, 1860, under Articles 23.9.3 and 81.2.3 (ICZN 1999). While the case is under consideration, Thecla azia Hewitson is to be maintained as the name for this species.

Lectotype designations. To provide both names under consideration here with unique name-bearing types, the female syntype deposited in the Naturhistoriska Riksmuseet, Stockholm, bearing the label "LECTOTYPE ? ㅇ/Thecla guacanagari/Wallengren, 1860/G. Lamas des. "92", is designated as the lectotype of Thecla guacanagari Wallengren; and the male syntype in the BMNH, bearing the label "Mexico/Hewitson Coll./79-69./Thecla/azia. 3.", as the lectotype of Thecla azia Hewitson, 1873..

\section{Strymon daraba (Hewitson, 1867)}

Thecla daraba Hewitson, 1867: 105.

Strymon daraba; Dos Passos, 1964: 57.

Thecla tyleri Dyar, 1913: 636, syn. nov.

Thecla daraba Hewitson, 1867, was described with text and a poorly illustrated male syntype (ventral wing surface only) "from the Amazon". After seeing specimens of $T$. yojoa Reakirt, [1867] lent to him by W.H. EDWARDS \& HEWITSON (1874) made $T$. daraba a junior synonym of $T$. yojoa. This action was widely followed (e.g., DRAUDT 1919-1920, COMSTOCK \& HUNTINGTON 19591964) until JOHNSON \& SALAZAR (1993) treated $T$. daraba as a different species, which had been subsequently described as Thecla tyleri Dyar, 1913. Thecla yojoa 
and T. tyleri were placed in different species groups of Strymon Hübner (ROBBINS \& NICOLAY 2002), despite a similar ventral wing pattern. The former is widespread from the United States to southern Brazil while the latter is endemic to the dry areas of western Ecuador, western Peru, northern Chile, and some dry inter-Andean valleys, such as the Río Marañón in Peru (RoBBins \& LAMAS unpubl. data).

Six individuals from HEWITSON's collection, identified as T. yojoa and listed by KIRBY (1879: 154), are labeled as HEWITSON's specimens 1-6 of T. yojoa in the BMNH. Four are female $T$. yojoa $(1,2,4,5$, with 1 and 5 from Mexico), one is male T. yojoa (6), and one is female T. tyleri (3, from Guayaquil). Specimens 2, 4, and 6 have no locality label, and none of these six specimens is labeled "Amazon" (indeed, no specimens from "Amazon" were mentioned by KIRBY [1879] among HEWITSON's yojoa). Specimens 1 (BMNH\# 266893) and 5 (BMNH\# 266892) have additional labels identifying them as female syntypes of Thecla beroea Hewitson, 1868 (BÁLINT unpubl. data), a subjective synonym of $T$. yojoa. Specimen 4 has a round, white with red border, label with "Type" printed in black, and the handwritten inscription (in black ink), "Thecla/daraba/Hew." on it, as well as an additional rectangular, white, label handwritten in black ink "not type,/because o/B[álint].Zs. VIII.30.[2000]". Specimen 6 (BMNH\# 266891) has three additional labels: one round, white with red border, with "Type" printed in black, and with " $\sigma^{\pi / T h e c l a / d a r a b a / H e w . " ~ h a n d w r i t t e n ~ i n ~ b l a c k ~ i n k ; ~}$ another rectangular, white, printed and handwritten in black ink with "B.M. TYPE/No. Rh. 1034"; the last rectangular, red with black border, printed and handwritten in black ink with "SYNTYPE ơ/Thecla/daraba/Hewitson/Zs. Bálint, 2000/London, VIII.30". Contrary to the assertion by JOHNSON \& SALAZAR (1993), there is no specimen in the $\mathrm{BMNH}$, either male or female, labeled "Hewitson Coll. 79-69. Thecla daraba 1. Amazon". They may have intended this to indicate the specimen "yojoa-6" referred to above, but such specimen does not correspond to their diagnosis of $T$. daraba, being instead a male $T$. yojoa, as indicated above.

The identity of Thecla daraba cannot be unequivocally determined from the original description and the figure of the underside wing pattern. Thecla tyleri is distinguished from $T$. yojoa on the hindwings by a relatively straight postmedian line and a small (to absent) orange cubital spot. The original figure has the straight postmedian line of $T$. tyleri and an orange cubital spot matching that found in $T$. yojoa. In addition, the third white band, just basal of the postmedian line, is too long for either species. Clearly, the figure is not a good one.

HEWITSON's collection contains many mislabeled or poorly labeled specimens (NELD pers. comm., LAMAS unpubl.), and this was sharply criticized, among others, by GODMAN (1892: li) who stated that " ... in a very large number of cases [HEWITSON] contented himself with giving the habitat of a species as simply Amazons, without any authority." On the other hand, his measurements were quite accurate, as he drew his figures "...by line and rule and compasses..." (EMBLETON 1880: 230).

Given the uncertain identity of $T$. daraba and the lack of HEWITSON specimens of $T$. yojoa from the Amazon, it is concluded that there is high probability that the female labeled "yojoa-3", with locality label "Guayaquil" is the specimen used by HEWITSON (1867: 105, pl. 36, fig. 89) as the model for his original figure of T. daraba. The general habitus and wing expanse $(24 \mathrm{~mm})$ of this specimen match HEWITSON's 
original figure and his wing expanse measurement $[19 / 20 "=24.1 \mathrm{~mm}]$. Only the sex of the specimen and its locality disagree with the original description. However, when HEWITSON (1874: 158) decided that both $T$. daraba and $T$. beroea were junior subjective synonyms of $T$. yojoa, he remarked that "misled by the much greater size of the Mexican specimens and the strongly marked discal spot of the male, I was induced to describe this [T. beroea] as a species distinct from those [T. daraba] I have from Guayaquil and the Amazon." He also indicated that the female of $T$. beroea (i.e., yojoa), which was not mentioned in the original description of 1868 , and so presumably came into his possession after that date, had "... a large dark brown discal spot on the anterior wing...", while no such distinctive forewing discal spot was mentioned originally for his "male" of $T$. daraba. It is believed that HEWITSON misidentified the sex of the specimen which served as model for his figure 89 , and that the original locality label "Amazon" was switched, misplaced or lost sometime before or at the time KIRBY inventoried the collection. HEWITSON's original locality labels are minuscule and easily misplaced or lost (LAMAS unpubl. data), although most of them have been glued to the undersides of accession labels added to the specimens after the collection went to the BMNH in 1879. Although most of the evidence is circumstantial, it is believed that the female labeled "Guayaquil" is a true syntype of $T$. daraba.

Lectotype designations. The female "yojoa-3" is selected as the lectotype of Thecla daraba and its type locality changed to Ecuador, Guayas, Guayaquil. This selection will preserve stable usage of the name Strymon yojoa (Reakirt), a species that ranges widely, as noted, and has been used in more than 30 publications by more than 10 authors in the past 50 years. Although T. tyleri now becomes a junior synonym of Strymon daraba syn. nov., this species has a restricted range compared to $S . y o j o a$, and the name has not been widely cited in publications.

To fix definitely the identity of the name Thecla beroea, the male specimen labeled "yojoa-6" mentioned above is designated its lectotype, even though it bears no locality label; this specimen matches best HEwITSON's original description and wing expanse $(13 / 20 "=29 \mathrm{~mm})$. The two females (yojoa-1 and yojoa-5) labeled by BÁLINT as syntypes of $T$. beroea quite clearly do not belong to the original type series; on the other hand, female "yojoa-4" (also not a syntype), without locality, in all probability is one of the specimens on which HEWITSON (1874: 158) based his diagnosis of female T. beroea (i.e., yojoa), as it is large (wing expanse, $28 \mathrm{~mm}$ ) and shows a conspicuous forewing dark brown discal spot.

\section{Hesperia columella Fabricius, 1793 nomen protectum}

Papilio dion Schaller, 1788 nomen oblitum.

The well-known Neotropical species, Hesperia columella Fabricius, 1793, has an older name, Papilio dion Schaller, 1788 which has not been used as a valid name after 1899 . To protect the stability of this younger, but widely used name, the older and virtually unknown Papilio dion is suppressed under Article 23.9.1 (ICZN 1999). In the appendix, more than 25 publications by more than 10 authors using the name Hesperia columella over the last 50 years are cited. By this action, Hesperia columella Fabricius, 1793 becomes a nomen protectum and Papilio dion Schaller, 1788 a nomen oblitum. 


\section{Thecla thoria Hewitson, 1869: 121}

Lectotype designation. Thecla thoria Hewitson, 1869, was described from at least three Venezuelan specimens, including two males, one of which "is without the black part of the discal spot, and has the other half paler and more distinct." To stabilize usage of this name, the male in the BMNH with the black part of the discal spot, labeled "B.M. Type No. Rh. 847", and "thoria-2", is designated as lectotype of Thecla thoria Hewitson. It occurs from Mexico to northern Venezuela and Colombia. The species without the black part of the discal spot, for which the name Thecla panchaea Hewitson, 1869, is available, ranges from the Amazon Basin to southern Brazil (Paraná), Paraguay, and Argentina.

\section{Thecla galliena Hewitson, 1877}

Thecla galliena Hewitson, 1877: 185.

Thecla iopas Godman \& Salvin, 1887: 65 syn. nov.

Lectotype designation. Thecla galliena Hewitson, 1877, was described from at least three males, one from Chontales, Nicaragua, one from Espírito Santo, Brazil, and one without stated locality. Syntypes from the first two localities represent two different species. To stabilize usage of this name, the male in the BMNH from Nicaragua, labeled "B.M. Type No. Rh. 869", and "galliena4", is designated as lectotype of Thecla galliena Hewitson. It occurs from Mexico to northern Venezuela and Colombia and is a senior synonym of Thecla iopas Godman \& Salvin, 1887, new synonym, which was also described from Chontales, Nicaragua.

\section{Nicolaea cupa (Druce, 1907) comb. nov.}

Thecla cupa Druce, 1907: 612.

Lectotype designation. Thecla cupa Druce, 1907, was described from at least one male and one female from Rio Grande [do Sul], Brazil. Two extant syntypes belong to different genera. To stabilize usage of this name, the male syntype in the BMNH, labeled "B.M. Type No. Rh. 815", is designated as lectotype of Thecla cupa Druce. It occurs in Paraguay and southern Brazil and is transferred to Nicolaea K. Johnson, 1993, comb. nov., as characterized in ROBBINS \& NICOLAY (2002).

ACKNOWLEDGMENTS. Thanks to: Phil Ackery, Kim Goodger, and Dick Vane-Wright of the Natural History Museum in London for many kindnesses, especially checking a number of facts and looking for the holotype of Thecla columbinia; to Jeff Glassberg and Paul Opler for helping us find North American references and confirming our identification of Ignata illepida; to John Eliot for confirming our identification of Thecla duma; to Sally Weschler for help with the illustrations; and especially to the many curators who kindly allowed us to examine specimens, particularly types, in the collections under their care. 


\section{REFERENCES}

ACKERY, P.R.; C.R. SMITH \& R.I. VANE-WRIGHT. 1995. Carcasson's African butterflies. An annotated catalogue of the Papilionoidea and Hesperioidea of the Afrotropical Region. East Melbourne, CSIRO Australia, XII+803p.

BRIDGES, C. 1988. Catalogue of Lycaenidae and Riodinidae (Lepidoptera: Rhopalocera). Urbana, Author, 788p.

Comstock, W.P. \& E.I. Huntington. 1959-1964. An annotated list of the Lycaenidae (Lepidoptera: Rhopalocera) of the Western Hemisphere. J. N. Y. Ent. Soc. 66: 103-118; 67: 59-95, 163-212; 68: 49-62, 105-122, 176-186, 232-240; 69: 54-58, 105-118, 157-176, 191-200; 70: 39-46, 100-118, 177-179; 71: 45-57, 115-119, 189-197, 262-264; 72: 62-64,120-130, 173-192.

Cowan, C.F. 1970. Annotationes rhopalocerologicae. Berkhamsted, Clunbury Press, 70p.

DRAudT, M. 1919-1920. Theclini F., p. 744-812. In: A. SEITZ (Ed). Die Gross-Schmetterlinge der Erde. 5. Die amerikanischen Tagfalter. Stuttgart, Alfred Kernen.

EBERT, H. 1969. On the frequency of butterflies in Eastern Brazil, with a list of the butterfly fauna of Poços de Caldas, Minas Gerais. Jour. Lepid. Soc. 23 (Suppl. 3): 1-48.

ELiot, J.N. 1973. The higher classification of the Lycaenidae (Lepidoptera): a tentative arrangement. Bull. Brit. Mus. (Nat. Hist.) (Entomol.) 28: 371-506.

Eliot, J.N. \& B. D'Abrera. 1992. The butterflies of the Malay Peninsula. Fourth Edition (revised). Kuala Lumpur, Malayan Nature Society, 596p.

Embleton, D. 1880. Memoir of the life of Mr. W. C. Hewitson, F.L.S. Nat. Hist. Trans. North-umberland, Durham, Newcastle-upon-Tyne 7: 223-235.

FABRICIUS, J.C. 1776. Genera insectorvm eorvmqve characteres natvrales secvndvm nvmervm, figvram, sitvm et proportionem omnivm partvm oris adjecta mantissa speciervm nvper detectarvm. Chilonii, Bartsch, [XIV]+310p.

Godman, F.D. 1892. The President's Address. Proc. ent. Soc. London 1892: XLVI-LIX.

HERRICH-SCHÄFFER, G.A.W. [1858]. Sammlung neuer oder wenig bekannter aussereuropäischer Schmettterlinge. Regensburg, G.J. Manz, Vol. 1, p. 53-84, pl. 23-24.

Hemming, A.F. 1967. The generic names of the butterflies and their type-species (Lepidoptera: Rhopalocera). Bull. Brit. Mus. (Nat. Hist.) (Ent.) (Suppl. 9): 1-509.

Hewitson, W.C. 1867. Illustrations of Diurnal Lepidoptera. Part I. Lycaenidae. London, John Van Voorst, (3): p. 77-114, pl. 31-46.

- 1874. Illustrations of Diurnal Lepidoptera. Part I. Lycaenidae. London, John Van Voorst, (6): p. 151-185 [sic], pl. 60-73.

.1877. Illustrations of Diurnal Lepidoptera. Part I. Lycaenidae. London, John Van Voorst, (7): p. 185-209, pl. 74-83.

HÜBNER, J. [1809]. Sammlung exotischer Schmetterlinge. 1. Augsburg, Jacob Hübner, pl. [97].

- [1819]. Verzeichniss bekannter Schmettlinge [sic]. Augsburg, Jacob Hübner, (2-8): 17-128.

ICZN. 1999. International Code of Zoological Nomenclature. London, International Trust for Zoological Nomenclature, $4^{\text {th }}$ ed., XXIX $+306 \mathrm{p}$.

Johnson, K.; G.T. Austin; J.F. LE Crom \& J.A. SalazAr. 1993. The Strephonina, a new infratribe of the

Eumaeini with description of fourteen new genera (Lycaenidae). Rev. Theclinae colomb. 1 (1): 1-61. Johnson, K. \& D. MAtusiK. 1989. Addendum: a new species of Tmolus (Lycaenidae) from Hispaniola, p. 525-529. In: A. SCHWARTZ (Ed.). The butterflies of Hispaniola. Gainesville, University of Florida Press.

Johnson, K. \& L.D. Miller. 1991. The genus Ministrymon Clench 1961 in Chile and a new species from the northern desert biotic province (Lepidoptera: Lycaenidae). Acta ent. chil. 16: 183-192.

JoHnSON, K. \& J.A. SALAZAR. 1993. New species, statuses and combinations in northern South American

Strymon (Lepidoptera, Lycaenidae, Theclinae). Rep. Mus. nat. Hist., Univ. Wisc. (Stevens Point) 26: 1-13.

KIRBY, W.F. 1871. A synonymic catalogue of diurnal Lepidoptera. London, John Van Voorst, 
$\mathrm{VII}+690 \mathrm{p}$.

. 1879. Catalogue of the collection of diurnal Lepidoptera formed by the late William Chapman Hewitson of Oatlands, Walton-on-Thames; and bequeathed by him to the British Museum. London, John Van Voorst, IV+246p.

LAMAS, G.; R.G. RoBbins \& W.D. FieLD. 1995. Bibliography of butterflies. An Annotated Bibliography of the Neotropical Butterflies and Skippers (Lepidoptera: Papilionoidea and Hesperioidea). In: J.B. HEPPNER (Ed.). Atlas of Neotropical Lepidoptera. Gainesville, Scientific Publishers, Vol. 124, $\mathrm{XIV}+463 \mathrm{p}$.

NolCKen, J.H.W. von. 1871-1872. Reisebriefe. Stett. ent. Ztg. 32: 258-267, 309-314, 371-380; 33: 123-136.

PAPAVERo, N. 1973. Essays on the History of Neotropical Dipterology. São Paulo, Museu de Zoologia da USP, Vol. 2, IV+217-446p.

POEY, F. 1832. Centurie de lépidoptères de l'Ile de Cuba, contenant la description et les figures coloriées de cent espèces de papillons nouveaux ou peu connus, répresentés d'après nature, souvent avec la chenille, la chrysalide, et plusieurs détails microscopiques. Paris, J.A. Mecklein, $4+[32]+[21]$ p., $20 \mathrm{pl}$.

PRITTwITZ, O.F.W.L. von.1865. Beitrag zur Fauna des Corcovado. Stett. ent. Ztg. 26: 123-143, 307-325.

RoBBINS, R.K.1991. Evolution, comparative morphology, and identification of the eumaeine butterfly genus Rekoa Kaye (Lycaenidae: Theclinae). Smithson. Contr. Zool. 498: I-III+1-64.

2002a. Replacement Names in the Eumaeini (Lepidoptera: Lycaenidae: Theclinae). Proc. ent. Soc. Wash. 104, in press.

. 2002b. Eumaeini. In: G. Lamas (Ed.). Checklist: Part 4A. Papilionoidea - Hesperioidea. In: J.B. HePpNER (Ed.). Atlas of Neotropical Lepidoptera. Gainesville, Scientific Publishers, in press.

RobBins, R.K. \& S.S. NicolaY. 1999. Taxonomy of Strymon toussainti, S. andrewi, S. amonensis, and S. rhaptos (Lycaenidae: Theclinae). Jour. Lepid. Soc. 52: 328-334.

- 2002. An overview of Strymon Hübner (Lycaenidae: Theclinae: Eumaeini). Jour. Lepid. Soc. 55: $85-100$.

SEYFFERT, O. 1995. The Dictionary of Classical Mythology, Religion, Literature, and Art. New York, Gramercy Books, 714p.

SMith, D.S.; L.D. Miller \& J.Y. Miller. 1994. The butterflies of the West Indies and South Florida. Oxford, Oxford University Press, X+264p.

WESTWOOD, J.O. 1850-1852. In: E. DOUBLEDAY. The genera of diurnal Lepidoptera: comprising their generic characters, a notice of their habits and transformations, and a catalogue of the species of each genus. London, Longman, Brown, Green \& Longmans, Vol. 2, p. 251-534.

\section{Appendix. List of publications using the name Hesperia columella Fabricius, 1793}

AlAyo, P. \& L.R. HERnÁnDEZ. 1987. Atlas de las mariposas diurnas de Cuba (Lepidoptera: Rhopalocera). La Habana, Editorial Científico-Técnica, [VIII]+148p.

Brown, F.M. \& B. Heineman. 1972. Jamaica and its butterflies. London, E.W. Classey Ltd., $\mathrm{XV}+478 \mathrm{p}$.

Brown, J.W.; H.G. Real \& D.K. FAulKner. 1992. Butterflies of Baja California. Faunal survey, natural history, conservation biology. Beverly Hills, Lepidoptera Research Foundation, Inc., $\mathrm{V}+129 \mathrm{p}$.

CaLhoun, J.V. 1997. Updated list of the butterflies and skippers of Florida (Lepidoptera: Papilionoidea and Hesperioidea). Holarct. Lepid. 4: 39-50.

ClenCH, H.K. 1964. A synopsis of the West Indian Lycaenidae, with remarks on their zoogeography. Jour. Res. Lepid. 2: 247-270.

D'Abrera, B.L. 1995. Butterflies of the Neotropical region. Part VII. Lycaenidae. Black Rock, Hill House, p. I-XI+1098-1270.

DeVRIES, P.J. 1983. Checklist of butterflies, p. 654-678. In: D.H. JANZEN (Ed.). Costa Rican natural 
history. Chicago, University of Chicago Press, 816p.

Emmel, T.C. \& J.F. Emmel. 1973. The butterflies of Southern California. Science Series. Nat. Hist.

Mus. Los Angeles County 26, XI+148p.

EnRico, P. \& R. Pinchon. 1969. Première partie. Les Rhopalocères ou papillons de jour des Petites

Antilles, p. 29-144. In: R. Pinchon \& P. ENRICO (Eds). Faune des Antilles françaises. Les papillons. Fort-de-France, Authors.

GASKIN, D.E. 1999. Butterflies of the Upper Frio-Sabinal region, central Texas, and distribution of faunal elements across the Edwards Plateau. Jour. Lepid. Soc. 52: 229-261.

Gerberg, E.J. \& R.H. ArnetT Jr. 1989. Florida butterflies. Baltimore, Natural Science Publications, $\mathrm{V}+90 \mathrm{p}$.

Glassberg, J. 1999. Butterflies through binoculars. The East. New York, Oxford University Press, $\mathrm{X}+242 \mathrm{p}$.

Glassberg, J.; M.C. Minno \& J.V. Calhoun. 2000. Butterflies through binoculars. A field, finding, and gardening guide to butterflies in Florida. New York, Oxford University Press, VIII+242p.

HowE, W.H. 1975. The butterflies of North America. New York, Doubleday \& Company, Inc., $\mathrm{XIII+633p.}$

LESTON, D.; D.S. SMITH \& B. LENCZEWSKI. 1983. Habitat, diversity and immigration in a tropical island fauna: The butterflies of Lignumvitae Key, Florida. Jour. Lepid. Soc. 36: 241-255.

MaZA, R.G. DE LA \& J. DE LA MAZA. 1993. Mariposas de Chiapas. México, Gobierno del Estado de Chiapas, 224p.

Meerman, J.C. 1999. Lepidoptera of Belize. Trop. Lepid. 10 (Suppl. 1): 1-61.

Miller, J.Y. 1992. The common names of North American butterflies. Washington, DC, Smithsonian Institution Press, IX+177p.

Miller, L.D. \& M.J. Simon. 1998. A preliminary annotated list of the butterflies (Lepidoptera: Rhopalocera) of Cat Island, Bahamas. Bahamas Jour. Sci. 6: 35-42.

Minno, M.C. \& T.C. EMmeL. 1993. Butterflies of the Florida Keys. Gainesville, Scientific Publishers, $\mathrm{VIII}+168 \mathrm{p}$.

Minno, M.C. \& M. MinNo. 1999. Florida butterfly gardening. A complete guide to attracting, identifying and enjoying butterflies of the Lower South. Gainesville, University Press of Florida, $\mathrm{XII}+210 \mathrm{p}$.

Opler, P.A. \& G.O. KRIZEK. 1984. Butterflies East of the Great Plains. An illustrated natural history. Baltimore, Johns Hopkins University Press, XVII+294p.

Opler, P.A. \& V. Malikul. 1992. A field guide to Eastern butterflies. Boston, Houghton Mifflin Company, XIX+396p.

Powell, J.A. 1958. Additions to the knowledge of the butterfly fauna of Baja California Norte. Lepid. News 12: 26-32.

Riley, N.D. 1975. A field guide to the butterflies of the West Indies. London, Collins, 224p.

Robiins, R.K. \& S.S. Nicolay. 1999. Taxonomy and nomenclature of Strymon istapa and S. columella (Lycaenidae: Theclinae: Eumaeini). Jour. Lepid. Soc. 52: 318-327.

SchwartZ, A. 1989. The butterflies of Hispaniola. Gainesville, University of Florida Press, XIV+580p.

ScotT, J.A. 1986. The butterflies of North America. A natural history and field guide. Stanford, Stanford University Press, XV+583p.

SMith, D.S.; L.D. Miller \& J.Y. MiLler. 1994. The butterflies of the West Indies and South Florida. Oxford, Oxford University Press, $\mathrm{X}+264 \mathrm{p}$.

Wetherbee, D.K. 1984. An instant survey of St. Croix, V.I. natural history. Boston, Author, 77p.

Received in 24.IX.2002; accepted in 26.VI.2002. 